\title{
Geosmithia morbida Found on Weevil Species Stenomimus pallidus in Indiana
}

Jennifer Juzwik, United States Forest Service, Northern Research Station, St. Paul, MN 55108; Mark T. Banik, United States Forest Service, Northern Research Station, Madison, WI 53705; Sharon E. Reed and James T. English, Division of Plant Sciences, University of Missouri, Columbia, MO 65211; Matthew D. Ginzel, Department of Entomology, Purdue University, West Lafayette, IN 47907

Accepted for publication 22 October 2014. Published 12 January 2015.

\section{ABSTRACT}

Juzwik, J., Banik, M. T., Reed, S. E., English, J. T., and Ginzel, M. D. 2015. Geosmithia morbida found on weevil species Stenomimus pallidus in Indiana. Plant Health Progress doi:10.1094/PHP-RS-14-0030

The canker pathogen Geosmithia morbida is known to be transmitted to Juglans species by the bark beetle Pityophthorus juglandis, and to lead to development of thousand cankers disease. In an Indiana-wide trap-tree survey of ambrosia and bark beetles and weevils colonizing stressed
Juglans nigra, G. morbida was detected on three Stenomimus pallidus weevils emerged from two trees on one site. This is the first report of the pathogen in Indiana and the first report of the fungus from an insect species other than $P$. juglandis.

\section{NTRODUCTION}

The health of eastern black walnut (Juglans nigra), a highly valued species in the eastern United States for timber and nut production, is threatened by thousand cankers disease (TCD) (9). Although first discovered in western states (10), the disease has recently been found in five eastern states (9) as well as in northeastern Italy (7)

TCD results from the interaction of the walnut twig beetle (Pityophthorus juglandis) (Coleoptera: Curculionidae: Scolytinae), a canker-causing fungus (Geosmithia morbida) (Ascomycota: Hypocreales: Bionectriaceae), and susceptible Juglans species (10). Walnut mortality attributed to mass attacks by the beetle and coalescence of numerous cankers resulting from concurrent inoculation of bark tissues by beetles carrying the fungus has been reported in eight western states and at least four eastern states $(11,13)$.

TCD detection efforts in the eastern United States have been based on visual surveys for symptomatic trees and on trapping for the insect using a walnut twig beetle sex pheromone lure (12). A trap tree survey was conducted in Indiana and Missouri in 2011 to augment the visual and insect trap surveys (8). Baseline data was also sought on other bark beetle species as well as ambrosia beetle and weevil species colonizing stressed J. nigra. Fungi associated with predominant insect taxa colonizing such trees were also of interest. Preliminary results of the broader study have been published (8). The detection of G. morbida on a weevil species obtained from one site in Indiana and the fungal assay technique used in the detection are reported here.

\section{STUDY SITES AND TRAP TREE ESTABLISHMENT}

Fifteen study sites were selected to give a wide geographical distribution in the state (Fig. 1), and for which landowner or land

Corresponding author: Jennifer Juzwik. Email: jjuzwik@fs.fed.us

doi:10.1094/PHP-RS-14-0030

This article is in the public domain and not copyrightable.

It may be freely reprinted with customary crediting of the source.

The American Phytopathological Society, 2015

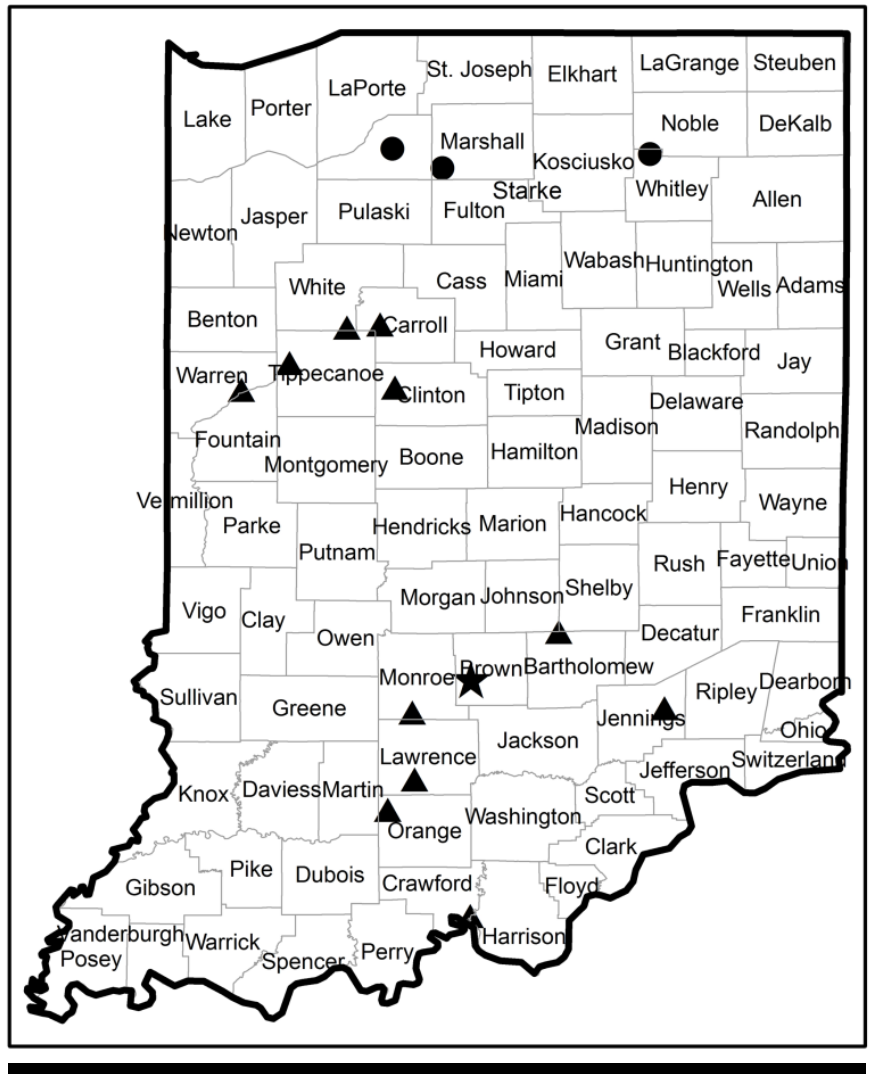

FIGURE 1

Locations of trap tree sites in the 2011 survey of ambrosia and bark beetles and weevils colonizing stressed black walnut in Indiana. $\star=$ the site with Geosmithia morbida-positive weevil; $\boldsymbol{\Delta}=$ sites with weevil specimens that were negative for G. morbida; and $\bullet=$ sites where neither S. pallidus nor G. morbida were detected. 
manager permission for killing black walnut trees and removing samples was obtained. All but one site was either a forest plantation or a group of wild-grown trees in or near a forest stand. The remaining site was in an urban orchard planting. Main stems of four J. nigra in each site were girdled in late May or early June 2011. Diameters of the girdled trees ranged from 15 to $25 \mathrm{~cm}$ at a 1.4-m height above the ground. Two parallel cuts were made on the lower stem of each tree using a chainsaw and a liquid herbicide (glyphosate) was immediately applied to the cuts. After 3 months, the trees were felled and two $30-\mathrm{cm}$-long main stem sections and one $30-\mathrm{cm}$ long segment from each of four branches in the crown were collected and placed in insect emergence buckets (6). Bark and ambrosia beetles and weevils obtained from collection cups on the traps between mid-September and midDecember 2011 were placed individually in sterile $1.5-\mathrm{ml}$ microcentrifuge tubes and stored at $-20^{\circ} \mathrm{C}$. All bark and ambrosia beetles were identified to species by the third author. All weevil species were identified by Dr. R. Hoebeke, Georgia Museum of Natural History, Athens, GA.

\section{ASSAY FOR PATHOGEN}

Subsets of individuals from each of six predominant insect taxa were assayed for G. morbida. These included four ambrosia beetles species (Xylosandrus germanus, X. crassiusculus, Xyleborus affinis, and Xyleborinus saxesenii), one bark beetle species (Pityophthorus lautus), and one weevil species (Stenominus pallidus). A dual assay system was developed to allow for detection of viable fungal propagules and of fungal DNA of species present on or in the selected specimens.

Processing began with grinding an insect with a mini-pestle in 40 $\mu \mathrm{l}$ of sterile molecular grade water (MGW) in a 1.5-ml centrifuge tube. For serial dilution plating, $20 \mu \mathrm{l}$ of the macerated beetle suspension was added to $320 \mu \mathrm{l}$ of sterile MGW. A second dilution then was created and three 100- $\mu$ l aliquots of each dilution were dispensed and spread on each of three 1/4-strength potato dextrose agar amended with streptomycin and chloramphenicol (1/4 PDA++) (11) in 100-mm diameter Petri dishes. Plates were incubated at room temperature $\left(24-25^{\circ} \mathrm{C}\right)$ under ambient lighting for 10 to 14 days. Any suspect isolates were transferred to new $1 / 4$ PDA++.

For the direct detection of fungal DNA, the remaining $20 \mu \mathrm{l}$ of macerated insect suspension was added to $80 \mu \mathrm{l}$ of a lysis buffer (MGW, 1.4 M NaCl, 0.1 M Tris-HCl, 20 mM EDTA, and 2\% CTAB adjusted to $\mathrm{pH} 7.0$ per Lindner and Banik [5]) in 600- $\mu \mathrm{l}$ tubes and stored at $-20^{\circ} \mathrm{C}$. DNA was extracted by heating the tubes at $65^{\circ} \mathrm{C}$ for $1 \mathrm{~h}$, centrifuging at $10,000 \mathrm{~g}$ at room temperature for $5 \mathrm{~min}$, and then removing $100 \mu \mathrm{l}$ of the supernatant to a $200-\mu$ strip-tube. DNA from each sample was precipitated with cold isopropanol at $-80^{\circ} \mathrm{C}$ and cleaned with glass milk (5). Cleaned DNA was re-suspended in $50 \mu \mathrm{MGW}$ and used as template DNA for PCR. The ITS (internal transcribed spacer) region was amplified using the fungal specific primer pair ITS1F and ITS4. The PCR reaction protocol, thermal cycler parameters, and cloning methodology used were those of Lindner and Banik (5), except water in the initial reaction was replaced with an additional $8 \mu$ of DNA template solution. Either 8 or 16 bacterial colonies, which had been successfully transformed with PCR products, were re-amplified in PCR as before. The resulting PCR products were diluted to approximately 1:10 with MGW and BigDye terminator cycle sequenced (ABI) using ITS1F primer per methods in Lindner and Banik (5). The resulting sequences were compared against known $G$. morbida ITS sequences using Sequencher version 5.0 sequence analysis software (Gene Codes Corp., Ann Arbor, MI).

\section{PATHOGEN ON WEEVILS}

No walnut twig beetles emerged from stem or branch samples in the emergence buckets. Four hundred thirty five adults of the weevil Stenomimus pallidus (Boheman) (Coleoptera:

Curculionidae: Cossoninae) (Fig. 2) were obtained, primarily from main stem samples of trees from twelve sites in Indiana. Fungal assays were conducted on 32 (2 to 6 per site) weevils of this species from these sites. DNA of G. morbida was detected on one of two $S$. pallidus initially assayed from one site (Brown Co.). Specimens had been stored at $-20^{\circ} \mathrm{C}$ between 5 and 8 months before laboratory processing of $S$. pallidus was completed. Based on this find, the remaining $S$. pallidus $(\mathrm{n}=19)$ from this site that had been in frozen storage for 23 to 25 months were then assayed. A G. morbida-specific primer (3' CGA CCC GGA CCC AGG CGA CCG 5') was paired with ITS4 for the PCR reactions in these assays. Two isolates of G. morbida were obtained from one weevil using serial dilution plating and DNA of G. morbida detected on a second one. The fungal isolates were tentatively identified as G. morbida based on colony morphology and microscopic characters (4) and subsequently verified by $\mathrm{N}$. Tisserat, Colorado State University, Ft. Collins, CO. DNA from one of the two isolates was extracted and amplified using the techniques previously described and the sequence (GenBank accession number KM879442) is 99\% identical to the G. morbida type isolate CBS124663 (GenBank accession number FN434082) (Table 1). The two sequences obtained from PCR + cloning and from direct amplification were sequenced as before except ITS-4 primer was used. These sequences (GenBank accession numbers KM879440 and KM879441) had 99 and 100\% identities, respectively, to previous accessions in GenBank (Table 1). In all, the fungus was detected on three $S$. pallidus emerged from two

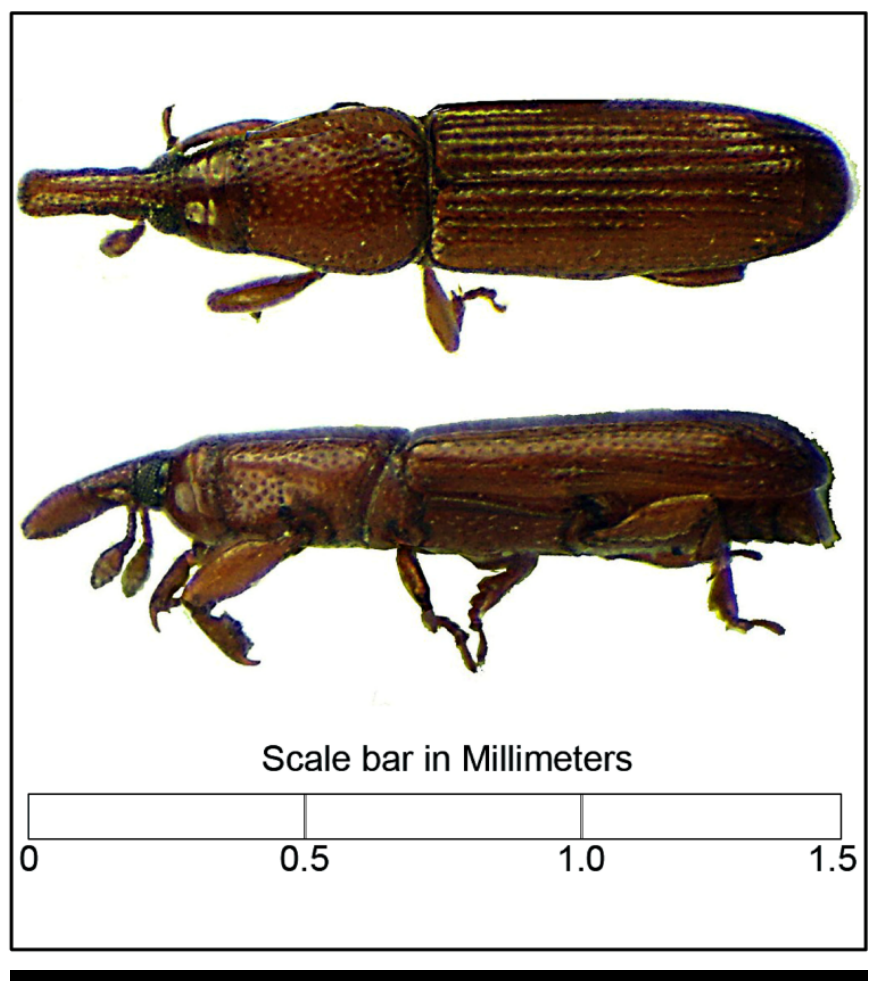

FIGURE 2

The weevil species, Stenomimus pallidus (Boheman), found to carry Geosmithia morbida in one site in Indiana. Length: $1.5 \mathrm{~mm}$. Photos kindly provided by J. C. Ciegler, West Columbia, SC. 
separate trees, or 3 of 21 specimens assayed, for this nonmanaged, black walnut plantation.

\section{ADDITIONAL ASSAYS OF INSECTS}

In response to this find, the State Plant Regulatory Official for Indiana requested that additional specimens of $S$. pallidus from the other eleven sites yielding the weevil be assayed. G. morbida was not detected via serial dilution plating or via direct DNA amplification for 107 additional S. pallidus from the other sites that were assayed (Table 2). Additionally, several ambrosia beetle species had been emerged from trap trees in the Brown Co. site as part of the larger study (8). G. morbida was not detected via isolation or via PCR + cloning of extracted DNA from the subset of species originally tested. In response to the G. morbidapositive weevil detection, additional specimens of the ambrosia beetles from the Brown Co. site were assayed by isolation and by direct DNA amplification (Table 3). G. morbida was not detected on Xylosandrus crassiusculus, X. germanus, Xyleborinus saxesenii, or Euwallacea validus in this second assay.

\section{SUMMARY AND IMPLICATIONS}

This is the first report of G. morbida from Indiana, the second report of the fungus occurring in a forested setting (Cataloochee Cove, Great Smoky Mountains National Park, NC) where walnut twig beetle has not been detected to date $(3,13)$, and the first report of the fungus from an insect species other than $P$. juglandis. The samples yielding the G. morbida-positive weevils were from black walnut whose crowns had no evidence of dieback or decline at the time of girdling. No attempt was made to peel the bark of the main stem or branch samples after the three months of insect collection ended in December 2011. Thus, it is not known the extent to which $G$. morbida cankers were present on the two trap trees. The nearest occurrences of G. morbida to the Brown Co. site are TCD-affected trees in Butler Co., OH (2), a distance of approximately $170 \mathrm{~km}$.

The low frequency of occurrence of G. morbida-positive $S$. pallidus suggests at least a very casual relationship between the fungus and the species. In contrast, G. morbida has been detected on $100 \%$ of $P$. juglandis emerged from stems and branches of TCD-symptomatic trees using the same molecular assay techniques in this report (J. Juzwik and M. Banik, unpublished data). Together, the low population density of S. pallidus and the low frequency of G. morbida detected on the species suggest that the weevil may not be capable of causing the numerous transmissions of the pathogen needed to adversely affect tree health. The known life cycle of S. pallidus is limited to its use of bark with larvae of S. pallidus found under the bark of wounded, living Carya sp. and under the bark of J. nigra and dead Quercus sp. (1). The weevil is generally distributed in the eastern United States. Specimens of $S$. pallidus in the Purdue Entomological Research Collection document its previously known existence in six Indiana counties. Of the insects emerged from walnut stem and branch sections obtained from the Brown Co. location, $G$. morbida was not detected on any of the assayed ambrosia beetles. This highlights the need to better understand the dissemination of G. morbida by insects, especially other bark-inhabiting insects such as weevils. Other weevil species were associated with black walnut in this study. The weevil, Himatium errans (LeConte) (Coleoptera: Curculionidae: Cossoninae) is generally distributed in eastern North America and was obtained from a number of trap tree samples in the larger trap tree study but not at the Brown Co. location (S. Reed, unpublished data). The potential for H. errans to transmit $G$. morbida should be investigated because the species is known to live in bark beetle galleries while the beetles are
TABLE 1

Geosmithia morbida isolates with the greatest percent nucleotide sequence identities to the sequences of the

fungus detected on Stenomimus pallidus in Indiana

\begin{tabular}{lllcc}
$\begin{array}{l}\text { Detection } \\
\text { method }\end{array}$ & \multicolumn{1}{c}{$\begin{array}{c}\text { Primers } \\
\text { used }\end{array}$} & $\begin{array}{c}\text { Accession } \\
\text { number }\end{array}$ & State & $\begin{array}{c}\text { Nucleotide } \\
\text { identities }\end{array}$ \\
\hline PCR + cloning & ITS 1F / ITS4 & HF546283.1 & CA & $557 / 559$ \\
& ITS 1F / ITS4 & FN434082.1 & CO & $557 / 559$ \\
& ITS 1F / ITS4 & FN434076.1 & CA & $557 / 559$ \\
Serial dilution & ITS 1F / ITS4 & FN434082.1 & CO & $558 / 559$ \\
plating & ITS 1F / ITS4 & FN434076.1 & CA & $558 / 559$ \\
DNA & ITS 4 / MOR3 & FN434082.1 & CO & $430 / 430$ \\
amplification & ITS 4 / MOR3 & FN811898.1 & $\ldots$ y & $430 / 430$ \\
& ITS 4 / MOR3 & FN434081.1 & CO & $430 / 430$ \\
\hline
\end{tabular}

y $G$. morbida type isolate

${ }^{\mathrm{z}}$ not available

TABLE 2

Numbers of Stenomimus pallidus assayed for Geosmithia morbida using both serial dilution and direct DNA amplification from 12 sites in Indiana

\begin{tabular}{|c|c|c|c|}
\hline \multirow{3}{*}{$\begin{array}{l}\text { County of } \\
\text { collection } \\
\text { site }\end{array}$} & \multicolumn{3}{|c|}{ Number of weevils } \\
\hline & \multicolumn{2}{|c|}{ Assayed ${ }^{y}$} & \multirow{2}{*}{$\begin{array}{c}\text { with } \\
\text { Geosmithia morbidc }\end{array}$} \\
\hline & 1st set & additional & \\
\hline Brown & 2 & 19 & 3 \\
\hline Caroll & 2 & 4 & 0 \\
\hline Clinton & 2 & 10 & 0 \\
\hline Crawford & 6 & 28 & 0 \\
\hline Jennings & 4 & 2 & 0 \\
\hline Johnson & 2 & 1 & 0 \\
\hline Lawrence & 2 & 3 & 0 \\
\hline Monroe & 2 & 3 & 0 \\
\hline Orange & 3 & 30 & 0 \\
\hline Tippecanoe & 2 & 2 & 0 \\
\hline Warren & 2 & 16 & 0 \\
\hline White & 3 & 12 & 0 \\
\hline
\end{tabular}

y 1st set molecular assay was PCR + cloning modification of Lindner and Banik (5); additional specimens molecular assay was direct amplification of fungal DNA.

\begin{tabular}{|c|c|c|}
\hline \multicolumn{3}{|c|}{$\begin{array}{l}\text { TABLE } 3 \\
\text { Numbers of ambrosia beetle species emerged from trap } \\
\text { trees on the Brown Co. site that yielded Geosmithia } \\
\text { morbida-positive Stenomimus pallidus, but were found to } \\
\text { be negative for the presence of the pathogen using serial } \\
\text { dilution plating and DNA amplification assays }\end{array}$} \\
\hline & \multicolumn{2}{|c|}{ Number of insects assayed ${ }^{y}$} \\
\hline Insect species & 1st set & additional \\
\hline Xylosandrus crassiusculus & 10 & 64 \\
\hline Xylosandrus germanus & 16 & 63 \\
\hline Xyleborinus saxesenii & 2 & 14 \\
\hline Euwallacea validus & $\ldots{ }^{\mathrm{z}}$ & 6 \\
\hline
\end{tabular}

y 1 st set molecular assay was PCR + cloning modification of Lindner and Banik (5); additional specimens molecular assay was direct amplification of fungal DNA.

z No E. validus was initially assayed.

present in galleries and after the beetles emerge (R. Hoebeke, personal communication).

There are significant implications of this report of G. morbida occurrence in Indiana because of the large volume of J. nigra growing stock in the state, the economic importance of walnut to the hardwood industry in the state, and of quarantine-related issues pertaining to movement of walnut within, into, and out of 
the state. Surveys for walnut twig beetle and G. morbida will be intensified in Brown Co. and counties bordering Butler Co., $\mathrm{OH}$, where TCD was found during 2012.

\section{ACKNOWLEDGMENTS}

This project was partially supported by a grant from the U.S. Forest Service, Forest Health Protection (Washington Office). We thank Brian Beheler, Lenny Farlee, and Matt Paschen for their assistance with site selection and field work.

\section{LITERATURE CITED}

1. Ciegler, J. 2010. Weevils of South Carolina (Coleoptera: Nemonychidae, Attelabidae, Brentidae, Ithyceridae, Curculionidae). Biota of South Carolina Vol. 6. Clemson University, Clemson, SC.

2. Fisher, J. R., McCann, D. P., and Taylor, N. J. 2013. Geosmithia morbida, Thousand cankers disease of black walnut pathogen, was found for the first time in southwestern Ohio. Plant Health Progress doi:10.1094/PHP2013-1201-BR.

3. Hadziabdic, D., Windham, M., Baird, R., Vito, L., Cheng, Q., Grant, J., Lambdin, P., Wiggins, G., Windham, A., Merten, P., and Taylor, G. 2013. First report of Geosmithia morbida in North Carolina: The pathogen involved in thousand cankers disease of black walnut. Plant Dis. doi:10.1094/PDIS-06-13-0630-PDN.

4. Kolařík, M., Freeland, E., Utley, C., and Tisserat, N. 2011. Geosmithia morbida sp. nov., a new phytopathogenic species living in symbiosis with the walnut twig beetle (Pityophthorus juglandis) on Juglans in USA. Mycologia 103:325-332. doi:10.3825/10-124.

5. Lindner, D. L., and Banik, M. T. 2009. Effects of cloning and root-tip size on observations of fungal ITS sequences from Picea glauca roots. Mycologia 101:157-165.
6. Mayfield, A. E., III, Fraedrich, W. W., Taylor, A., Merten, P., and Myers, S.W. 2014. Efficacy of heat treatment for the thousand cankers disease vector and pathogen in small black walnut logs. J. Econ. Entomol. 107:174-184.

7. Montecchio, L., and Faccoli, M. 2013. First record of thousand cankers disease Geosmithia morbida and walnut twig beetle Pityophthorus juglandis on Juglans nigra in Europe. Plant Dis. 98:696. doi:10.1094/PDIS-10-13-1027-PDN.

8. Reed, S., English, J., Juzwik, J., and Ginzel, M. 2013. Bark and ambrosia beetles and their associated fungi colonizing stressed walnut in Missouri and Indiana. Walnut Council Bull. 40(2):17-19.

9. Seybold, S., Haugen, D., and Graves, A. 2013. Thousand cankers disease. Pest Alert NA-PR-02-10 rev. February 2013. Northeastern Areas State and Private Forestry, USDA Forest Service.

http://na.fs.fed.us/pubs/palerts/cankers_disease/thousand_cankers_disease screen_res.pdf

10. Tisserat, N., Cranshaw, W., Leatherman, D., Utley, C., and Alexander, K. 2009. Black walnut mortality in Colorado caused by the walnut twig beetle and thousand cankers disease. Plant Health Progress doi:10.1094/PHP-2009-0811-01-RS.

11. Tisserat, N., Cranshaw, W., Putnam, M. L., Pscheidt, J., Leslie, C. A., Murray, M., Hoffman, J., Barkley, Y., Alexander, K., and Seybold, S. J. 2011. Thousand cankers disease is widespread in black walnut in the western United States. Plant Health Progress doi:10.1094/PHP-20110630-01-BR.

12. USDA Forest Service and Plant Protection and Quarantine. 2013. Thousand cankers disease survey guidelines for 2013. http://www.thousandcankers.com/media/docs/TCD Survey Guidelines 2 013.pdf

13. Wiggins, G. J., Grant, J. F., Lambdin, P. L., Merten, P., Nix, K. A., Hadziabdic, D., and Windham, M. T. 2014. Discovery of walnut twig beetle, Pityophthorus juglandis, associated with forested black walnut, Juglans nigra, in the eastern U.S. Forests 5:1185-1193. doi:10.3390/f5061185. 